\title{
РОЛЬ «ІСТОРИЧНОЇ ГРАМАТИКИ УКРАЇНСЬКОЇ МОВИ» В ПІДГОТОВЦІ ВЧИТЕЛЯ-СЛОВЕСНИКА
}

Колоїз Ж. В. Роль «Історичної граматики української мови» в підготовці вчителясловесника.

У статті йдеться про роль «Історичної граматики української мови» в підготовці майбутніх учителів-словесників; аналізуються історичні процеси, передусім фонетичні, що сприятимуть кращому засвоєнню програмового матеріалу, зокрема під час вивчення історичних чергувань, спрощення у групах приголосних і т. ін.

Ключові слова: історична граматика, історичні коментарі, фонетичні процеси, філологічна підготовка.

Колоиз Ж. В. Роль «Исторической грамматики украинского языка» в подготовке учителя-словесника.

В статье исследуется роль «Исторической грамматики украинского языка» в подготовке будущих учителей-словесников; анализируются исторические процессы, прежде всего фонетические, способствующие лучшему усвоению программного материала, а именно при изучении исторических чередований, упрощении групп согласных.

Ключевые слова: историческая грамматика, исторические комментарии, фонетические процессы, филологическая подготовка. 
Koloyiz Zh. V. The role of "The Ukrainian language historical grammar" in future philologist training.

The article investigates the role of "The Ukrainian language historical grammar" in future philologist training, gives the analysis of historical processes, first of all phonetic that promote better mastering of program material, especially when studying historical alternation and simplification in groups of consonants.

Key words: historical grammar, historical comments, phonetic processes, philological training.

«Історична граматика української мови», як відомо, - це мовознавча дисципліна, що вивчає формування та розвиток української мови, ті зміни, що відбувалися в іiі системі в напрямку до вдосконалення [1, с. 3-4]. Ці зміни охоплюють здебільшого всі мовні рівні, а тому як назва наукової та навчальної дисципліни «Історична граматика»- назва умовна, оскільки передбачає вивчення не лише граматичної будови української мови, а й іiі фонетичної системи, словотворчих особливостей, лексичного складу. Основним завданням «Історичної граматики української мови» $\epsilon$ виявлення загальних закономірностей та тенденцій становлення фонетичного та граматичного рівнів мовної системи $[1 ; 4 ; 6]$. Значення цього курсу полягає в тому, що він забезпечує повне, усебічне розуміння мовних явищ, бо показує їх не тільки в розвитку, але i в зв'язках із відповідними явищами в споріднених мовах; демонструє взаємозв'язок у розвитку структурних елементів мови; засвідчує стійкість граматичної будови мови та іiі основної лексики. Про це неодноразово наголошували видатні вітчизняні науковці (О. Безпалько, М. Бойчук, М. Жовтобрюх, Ф. Медведєв, В. Скляренко, І. Тараненко, О. Царук та ін.). Опанування названого курсу $є$ обов'язковим для кожного майбутнього словесника, адже сприяє кращому розумінню сучасної української літературної мови, передусім iі фонетичних і граматичних явищ. Щоправда, на шляху до якісного засвоєння відповідної дисципліни виникає ряд проблем, як-от: відсутність нових підручників і посібників, рекомендованих Міністерством освіти i науки України (у своєму розпорядженні студенти мають переважно праці, видані ще за радянських часів [1; 4; 6]), зменшення кількості аудиторних годин на вивчення курсу (50 годин, з яких лекційних 26 год., практичних - 24 год.) і т. ін. Натомість роль «Історичної граматики української мови» в підготовці майбутнього вчителя-словесника (i не тільки!) незаперечна. А відтак методика викладання цієї дисципліни у вищих навчальних закладах потребує неабиякої уваги.

У запропонованій статті ми зробимо спробу обгрунтувати важливість історичних коментарів для опанування сучасної української літературної мови загалом і ïi фонетичної системи зокрема.

Цілком закономірно, що «Історичній граматиці української мови» передує вивчення інших дисциплін так званого історичного циклу, як-от: старослов'янська мова (найдавніша слов'янська літературна мова). Дослідження помилок, які робили українські переписувачі 
церковнослов'янських книг, дозволяе зробити певні висновки про фонетичні та граматичні особливості староукраїнської мови. Аналіз мови й письма датованих пам'яток часто допомагає хронологізувати мовні явища, допомагає визначити особливості мови того чи іншого періоду [4, с. 6-10].

Неабияке значення для розуміння історичних фонетичних $\mathrm{i}$ граматичних явищ має й діалектологія. Діалекти української мови часто зберігають у своїй структурі ті звуки, форми та конструкції, які вже втрачені літературною мовою. Наприклад: пам'ятками письма не можна визначити шлях, який пройшли в українській мові давні голосні $[o],[e]$, поки вони не змінилися в $[i]$ у словах на зразок стіл, шість (письмові пам'ятки фіксують тільки початковий етап цього процесу: $[o]>\boldsymbol{o o},[e]>\mathbf{k}$, сучасні ж північноукраїнські діалекти містять на місці цих голосних дифтонги). Крім того, ряд фонетичних і граматичних процесів у діалектах розвивається шляхом, не властивим літературній мові [1, с. 11].

Історія української мови доповнюється також лексичними запозиченнями та топонімічними назвами. Запозичені слова підлягають законам тієї мови, що їх засвоює, а це веде до звукових змін у вимові засвоєних слів, наприклад: староукраїнська вимова слова Ігор (запозичене в X ст. зі скандинавської мови - Ingvar) засвідчує, що в цей час у староукраїнській мові носових уже не було, бо інакше з Ingvar витворилося б Ягор, а не Ігор [1, с. 14].

Проблемним до сьогодні залишається й питання щодо походження української мови. Донедавна єдино правильною вважалася позиція, згідно 3 якою початок формування української мови, як i російської та білоруської, припадає на XIII-XIV ст., період падіння середньовічної Київської держави. Більшість наявних підручників чітко ілюструють періодизацію історії української мови в дусі радянського мовознавства [5, с. $8 ; 6$, с. $23 ; 8$, с. 17-19]. Мовою-основою («материнською колискою») української, російської і білоруської мов проголошувалася давньоруська [2, с. $12-15 ; 3$, с. $31-35]$, незважаючи на те, що в мовознавстві, зокрема в україністиці, існували й існують інші думки науковців, які заперечують монолітну давньоруську народність (М. Грушевський, С. Смаль-Стоцький, €. Тимченко, К. Німчинов та ін.), натомість визнають наявність східнослов'янських племен зі своїми близькими, але не тотожними мовами. Як зауважує В. Русанівський, тут виокремлюються племена, які виявляють проукраїнські етнічні риси, щоправда, початок їхнього існування ще не встановлено. Термін «давньоруська мова» учений пов'язує $з$ літературною мовою східних слов'ян, основу якої становила старослов'янська (староболгарська) [2, с. 12]. С. Бевзенко, вважаючи V ст. початок VI ст. періодом розпаду праслов'янської мови, формування фонетичної природи української мови відносить до XII ст., а початок іiі шукає в VII-VIII ст., коли стався розрив між слов'янськими племенами [2, c. 14]. 
Правильному розумінню історії української мови перешкоджала так звана погодінська гіпотеза [8, с. 18], що належала російському історику М. Погодіну, була викладена ним у праці «Записки о древнем языке русском» (1856р.) Суть іï полягала в тому, що, на думку дослідника (пізніше його підтримав i російський академік О. Соболевський), у стародавньому Києві й на Київщині в час становлення руської державності й до татаро-монгольської навали жили тільки великороси, малоросів тут не було. Про це, за М. Погодіним, свідчить нібито тотожність книжної мови, встановлена I. Срезневським. А давньоруська книжна мова, зазнавши впливу з боку запозиченої старослов'янської мови, виявляє більшу схожість із мовою російською, а не українською. Українці прийшли сюди із Заходу, десь із Галичини і Волині чи із-за Карпат, після виходу росіян на північ під тиском монголо-татар. Вони, тобто українці, заселили спустошену Київщину не раніше кінця XV ст. Погодінську гіпотезу аргументовано спростував ще М. Максимович. А сьогодні все більшої популярності набуває періодизація розвитку української мови за М. Грушевським. Учений переконливо довів що, етнічні українські землі ще до часів Київської Русі заселяли українці; заперечив шовіністичні версії про початок української історії (народу і мови) лише 3 XIV - XV ст.; ототожнював українців із народом Дніпрово-Бузької держави II - VII ст., яка в іноземному світі отримала назву Антська; українську мову виводив безпосередньо 3 праслов'янської. Схематично це можна зобразити так: період спільноіндоєвропейської мови (до II тис. до н. е.) $\rightarrow$ період слов'яно-литовської мовної групи (до $\mathrm{V}$ ст. до н. е.) $\rightarrow$ період розпаду слов'яно-литовської мовної групи (з V ст. до н. е. до І ст. н. е.) $\rightarrow$ праслов'янська мова (до VI ст. н. е.) [8, с. 18]. Після праслов'янського періоду в розвитку української мови Ю. Шевельов виділив такі періоди: 1) протоукраїнська мова (з VII ст. до XI); 2) староукраїнська мова (з XI ст. н. е. (часу появи перших писемних пам'яток) до кінця XIV ст.); 3) середньоукраїнська мова (кінець XIV ст. до початку XIX ст.); 4) нова українська мова (з початку XIX ст.) [9, с. 13].

Хронологізація відповідних історичних, зокрема фонетичних, явищ, заглиблення в їхню природу, iї осмислення і т. ін. дасть змогу майбутнім словесникам чітко зорієнтуватися в історії формування та становлення сучасної української літературної мови, сприятиме виробленню вмінь і навичок передусім етимологічного аналізу - однієї зі складових лінгвістичної підготовки.

Чимало історичних фонетичних процесів пов'язані 3 так званим законом відкритого складу, який виник ще в дописемний період історії української мови і припинив свою дію в кінці XI - першій половині XII ст. Суть його полягала в тому, що звуки в складах розмішувалися за наростаючою звучністю, тобто склад починався 3 менш звучного i закінчувався більш звучним. За таких умов у кінці складу стояли лише 


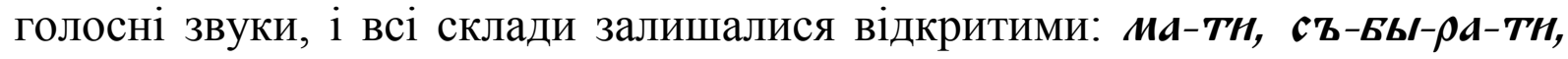
cтt'-на, cz-нz. За цим законом були певні обмеження і щодо збігу приголосних у межах одного складу. Два приголосні, скажімо, шумний + сонорний, розміщувалися за тенденцією висхідної звучності: пра-вь-да, злн-тн. Перетворення фонетичної системи праслов'янської мови в результаті дії закону відкритого складу пов’язуються з цілим рядом змін, зокрема: 1) втратою кінцевих приголосних: *sūnŭs > сынz; *plŏdŏs > пиодz; 2) спрощенням груп приголосних; 3) зміною дифтонгів на монофтонги (утворення носових голосних); 4) розвитком повноголосся тощо.

Із законом відкритого складу пов'язується зміна звукосполучень [* $d t]$, $[* t t]$ в [*st] передусім в інфінітивних формах дієслова, яка покликана дати відповідь на питання: чому, скажімо, в сучасній українській мові кореневі морфеми неозначених форм дієслова на зразок брести, плести, мести, вести тощо відрізняються від форм теперішнього часу (бреду, плету, мету, веду)? Річ у тім, що звук [*t] дієслівної основи і звук $\left[{ }^{*} t\right]$ інфінітивного суфікса належали до різних складів, а тому склад перед



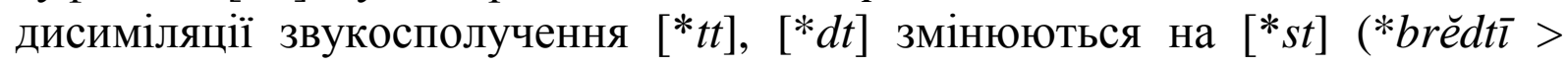

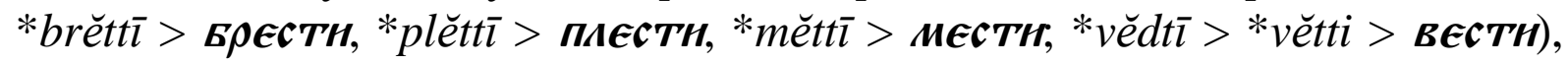

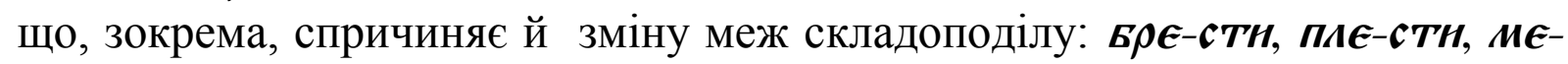

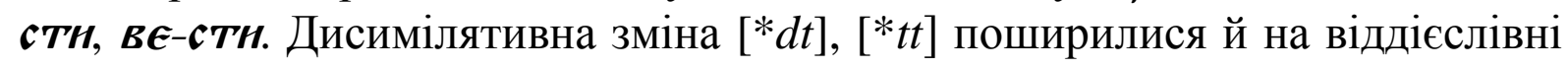

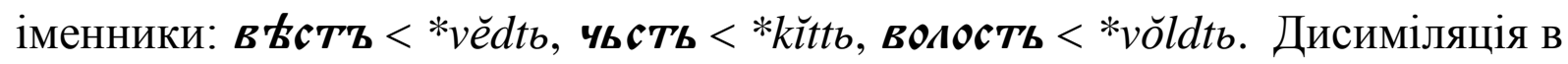
групах приголосних $[* d t],[* t t]$ викликала чергування звуків $[\partial],[m], 3[c]$, яке засвідчує сучасна українська мова.

Наявність багатьох варіантних морфем пояснюється також i спрощенням у групах приголосних. Це дає змогу пояснити, чому, скажімо, у сучасній літературній мові згинути, але загибель, кинути, але кидати, спати, але сон і т. ін. Такі звукові розбіжності, власне, й стосуються відповідних спрощень, зумовлених дією закону відкритого складу, як-от: приголосні $\left[{ }^{*} b\right],\left[{ }^{*} p\right],\left[{ }^{*} g\right],[* d]$ перед звуком $\left[{ }^{*} n\right]$ наступної морфеми занепали, наприклад: *sŭgūbnŏntī > *sŭgūnŏntī > съгынк тн> съгыноутн >

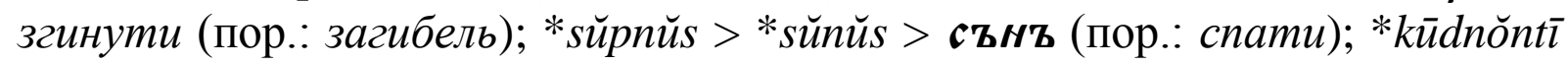
> *kūnŏntī > кынктн > кыноутн > кинути (пор.: кидати). У зв’язку 3 законом відкритого складу спростився й [*v] на початку кореня після префікса [*ob], наприклад: *ŏbvŏzŏs > овозz > обоз (пор.: возити); *ŏbvŏorŏtŏs > оворот' > оборот (пор.: nоворот).

3 дією закону відкритого складу пов'язується й перше повноголосся зміна праслов'янських звукосполучень [*or], [*ol], [*er], [*el] між приголосними в повноголосні звукосполучення [оро], [оло], [ере], [еле]. У протоукраїнській мові плавні $[p],[л]$ втратили складотворчість і перетворилися на звичайні приголосні. Це зумовлювало виникнення закритих складів, не властивих протоукраїнській мові того часу. Розвиток 
після $[p]$, [л], коли вони втратили складотворчу властитвість, нових голосних, аналогічних до тих, що стояли перед ними, i дав змогу уникнути закритості складів. Після сонорних $[p],[л]$ голосні $[o],[e]$ розвинулися не відразу. Спершу, очевидно, коли сонорні втратили складотворчу

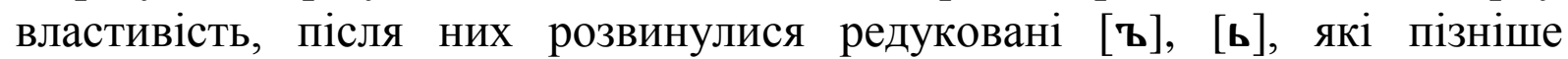
змінилися в голосні повного творення $[o],[e]: * b \check{o r d a}>\mathbf{6 0 \rho \mathbf { z }} \mathbf{a}>$ борода; *vŏlsŏs > вонъcz > волос; *děrvŏ > дерьво > дерево; *mĕlkŏ > *mŏlkŏ >

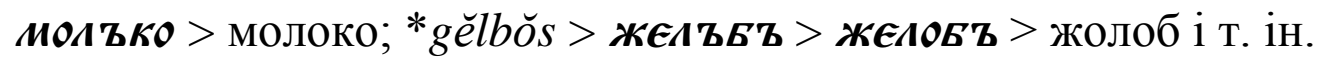

Південнослов'янські та західнослов'янські мови, крім польської, у словах зі звукосполученнями $[* o r],\left[{ }^{*} o l\right],[* e r],[* e l]$ між приголосними уникали закритих складів через метатези-перестановки місця голосного

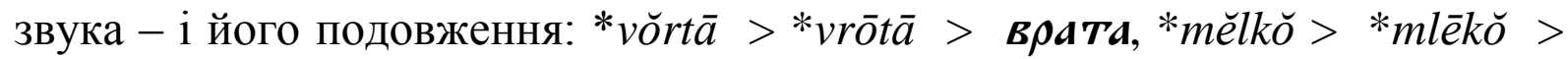
ми tко. У польській мові ці звукосполучення, як і в протоукраїнській, розвинулися спершу в повноголосні форми; етимологічні $[o],[e]$ поступово редукуються і зникають: *bŏrdā > bŏrъdā > boroda > broda; *bĕrgъ > běrbgъ > breg. Знання подібних фонетичних особливостей дасть змогу студентові орієнтуватися в походженні тієї чи тієї лексеми. Так, наприклад, ніколи і ні в кого не виникало жодних сумнівів щодо спорідненості слів боронити - броня; володіти - влада; порох - прах; ворог - вражсии; хороми храм тощо. Їхні фонетичні відмінності ілюструють різні шляхи звукових модифікацій у різних групах слов'янських мов: повноголосні форми (боронити, володіти, порох, ворог, хороми) демонструють закономірні фонетичні процеси, характерні для східнослов'янських мов; наявність на місці повноголосних форм звукосполучень $p a$, ла (влада, прах, вражий, храм) засвідчує особливості південнослов'янських мов; звукосполучення ро у слові броня репрезентує його західнослов'янське (польське) коріння (пор.: золото, златo, zloto (пор. : назву грошової одиниці в Польщі).

Дією закону відкритого складу зумовлена й поява носових голосних, що позначалися літерами $\boldsymbol{\boldsymbol { \pi }}$ (юс великий), $\boldsymbol{\boldsymbol { A }}$ (юс малий). Голосний $o$ носовий утворився зі сполучень чистого голосного непереднього ряду та носового приголосного $([* m],[* n])$, якщо вони закривали склад: *zvŏnkŭs >


носовий утворився зі сполучень чистого голосного переднього ряду та носового приголосного: *sēmĕn > сtмs (сім'я (рос. семена), *dĕsӗnť̆s > десать (десять), *pŏkĭntī > початн (почати; цікавим є те, що сучасні слова початок і кінець є етимологічно спорідненими).

У кінці IX - на початку Х ст. $o$-носовий змінився на $[y]$, а $e$-носовий на $[' a](я)$. Деназалізація носових голосних відбулася в усіх слов'янських мовах, крім польської і кашубської. Зміна звукосполучень *om, *on, *um, *un, *em, *en,*im, *in у кінці складу на носові голосні та подальша їхня деназалізація зумовили появу цілого ряду звукових чергувань, відомих сучасній українській мові: $[a]-[H]-[u н]:$ почати - почну - почин; $[a]-$ 
$[м]-[u м]:$ жати - жму - пожимати; $[y]-[м]-[u м]:$ дути - дму надиматися тощо. Звуки $[a],[y]$, які чергуються $3[H],[м]$ (або звукосполученнями голосний + носовий), історично розвинулися з носових звуків, що позначалися літерами $\boldsymbol{\pi}, \boldsymbol{A}$, виникли з дифтонгічних сполучень, які закривали склад. Це дає можливість стверджувати: слова на зразок звук і дзвонити етимологічно споріднені й мали абсолютно однаковий корінь *zvŏnkŭs > звћкъ > звук; *zvŏnīt носовий звук закривав склад, а відтак дифтонгічне звукосполучення монофтонгізувалося, змінилося в $o$-носовий з подальшою деназалізацією; в іншому - складоподіл проходив так, що голосний відійшов до попереднього складу, носовий приголосний - до наступного, оскільки стояв перед голосним.

Згідно 3 іншим законом - законом складового сингармонізму (від грецьк. syn - разом, garmonia - стрункий порядок, зв'язок) - у межах одного складу могли поєднуватися тверді приголосні та голосні непереднього ряду або, навпаки, м'які приголосні та голосні переднього ряду. Якщо ж порушувалася ця закономірність, то відбувалося пристосування артикуляцій приголосного і голосного звуків, причому це пристосування могло виявляти різний характер. Результатом закону складового сингармонізму стали перехідні пом'якшення, або палаталізації, задньоязикових. Так, скажімо, чергування задньоязикових $[\kappa],[x]$ та глоткового [2] в сучасній українській літературній мові із шиплячими [u], [u], [ж] (бог - боже, друг - друже, вік-вічний, вухо - вушко, ріг - ріжок) $\epsilon$ історичними, пов'язані 3 першим перехідним пом'якшенням, яке відбулося ще III - IV ст. до н. е. (задньоязикові $\left[{ }^{*} g\right],\left[{ }^{*} k\right],\left[{ }^{*} c h\right]$, перед голосними переднього ряду [i] (позначався літерою и), [e], [e], [b], [ie], що позначався літерою $\mathbf{k}$, змінилися на $[\varkappa],[u],[w]$, наприклад: *nŏgǐk $\bar{a}>$

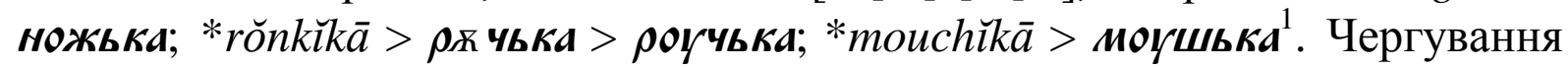
задньоязикових [к], [x] та глоткового [2] із [u], [c] , [з] (мох - (у) мосі, луг (у) лузі, молоко - (у) молоці) з позицій «Історичної граматики української мови» розглядається як результат другого перехідного пом'якшення, що відбулося в I ст. н. е. (зміна задньоязикових $[* g],[* k],\left[{ }^{*} c h\right]$ перед голосними переднього ряду $[i](\boldsymbol{H}),[i e](\boldsymbol{t})$, які походять із дифтонгів, на

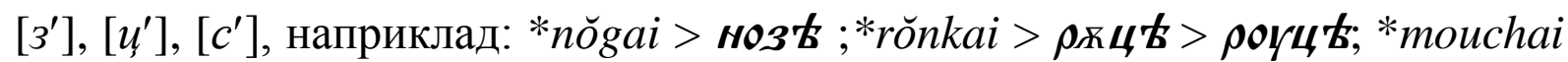
$>$ моус $\boldsymbol{t}$. Перед $\mathbf{t}<* o i$ могли змінюватися також звукосполучення [*gv], $\left[{ }^{*} k v\right]$ на $\left[3^{\prime} 6\right],\left[u^{\prime} 6\right]$, але лише в давніх східнослов'янських i

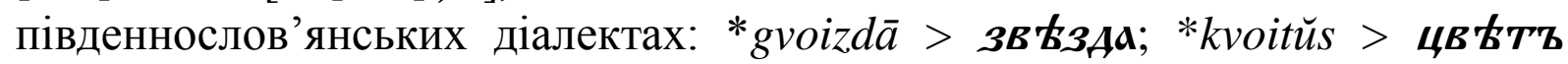
(але: у польській мові gwiazda, kwiat; чеській kvet, hvezda).

Сучасній українській літературній мові відомі чергування в системі приголосних, що пояснюються пом’якшенням приголосних у сполученні 3

1 У словах на зразок жінка (жона), чадо також відбувалися аналогічні фонетичні процеси: жона < жена < *genas (пор. : гени, гінеколог; чадо < члдо < *kindo (пор. : нім. Kinder). 
*j. Останній у праслов'янській мові належав до складу іменникового або дієслівного суфікса, зумовлював пом'якшення приголосних, після яких стояв, а це викликало різні їхні зміни, унаслідок чого виникали звукові чергування, наприклад: $\left[{ }^{*} k j\right]>[u]: *$ pläkjŏs > плачb; $[* c h j]>[u]: * d o u c h j \bar{a}$

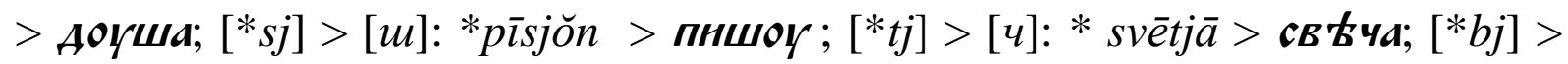

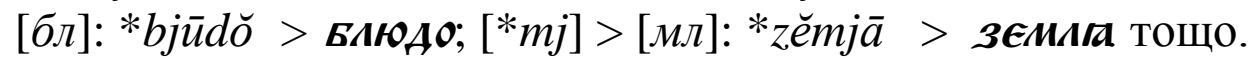

Якщо історичні чергування в системі приголосних сучасної української літературної мови сягають праслов'янської доби, то чергування в системі голосних пов'язані здебільшого з історією звуків, що характеризувалися надкороткою вимовою, і кваліфікуються в лінгвістиці як редуковані. Як відомо, редуковані голосні [b], [b] були в усіх слов'янських мовах, але в жодній із них не збереглися. У староукраїнській мові редуковані існували ще в XI ст. та першій половині VII ст. Доказом цього $\epsilon$ те, що в писемних пам'ятках того часу майже послідовно вживалися букви $\mathbf{z}, \mathbf{6}$. Доля редукованих залежала від їхнього місця у слові, інакше кажучи, від сильної чи слабкої позиції.

Голосні [ъ], [b] у слабкій і сильній позиції вимовлялися неоднаково: у слабкій позиції вони були коротшими, ніж у сильній. У слабкій позиції редуковані занепали, у сильній - змінилися на голосні повного творення, відповідно, $[b]>[o],[b]>[e]$. Це, власне, спричинило не лише припинення дії закону відкритого складу та зменшення кількості голосних ще на два звуки ${ }^{2}$, але й такі специфічно українські чергування, як-от: чергування $[o],[e]$ 3 нулем звука; чергування $[o]$ з $[u]$ після сонорних $p, \pi$; чергування $[o],[e]$ з $[i]$.

Після вокалізації редукованих [b], [b] у сильній позиції почали розрізняти голосні $[o],[e]$ давні, первинні, етимологічні, успадковані від спільноіндоєвропейської мови, та $[o],[e]$ нові, вторинні, секундарні, що виникли на місці редукованих у сильній позиції: съ тьнг > сотня, $\mathfrak{c z} \mathbf{z z}>$ сон, пъczкъ > пісок, дьнь > день, орьдь > орел і т. ін. Редуковані [b], [b] у різних формах одного і того ж слова могли бути і в сильній, і в слабкій позиції. У сильній позиції вони переходили, відповідно, в $[o],[e]$ секундарні, а в слабкій - повністю зникали. Унаслідок цього й виникло чергування секундарних $[o],[e]$ з нулем звука: пісок - піску ( $\mathbf{k c z k z}-\boldsymbol{n} \mathbf{t c z \kappa a ) , ~ о р е л ~}$

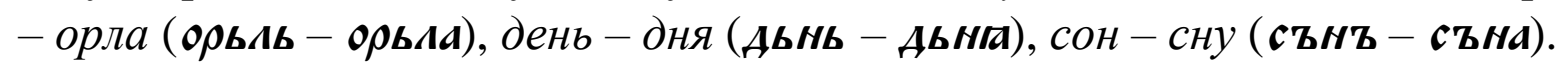

\footnotetext{
2 Загалом же система голосних староукраїнської мови початкового періоду була представлена одинадцятьма голосними. Після деназалізації носових їх стає дев'ять. Занепад (чи то вокалізація) редукованих залишає в системі голосних сім звуків, що згодом модифікується до

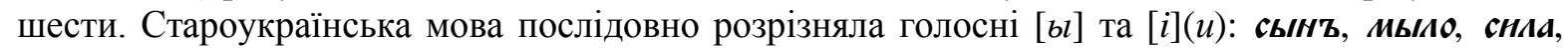
внтн. Завдяки поступовому обниженню творення давнього [i] $(u)$ відбулося зближення артикуляції староукраїнських звуків $[b l]$ та $[i](u)$, унаслідок чого вони збіглися в одному звукові $[u](u)$, голосному передньо-середнього ряду й середньо-високого піднесення, який не мав здатності пом'якшувати приголосні, після яких стояв: риба < рыба, язик < азкъ крик < крыкъ, живіт < жнвотъ. Система голосних сучасної української літературної мови представлена шістьома фонемами.
} 
Голосні $[o],[e]$, які чергуються з нулем звука, називаються випадними. Ïм протиставляються вставні $[o],[e]$, які виникли внаслідок занепаду редукованих $[b],[b]$ на кінці слів після сонорних $[p],[\pi],[м],[н]$, перед якими стояв інший приголосний. Якщо сонорний, після якого занепадав редукований, стояв після приголосних $[\tau],[\kappa],[x]-$ з'являвся вставний $[o]$ (огнь > вогонь; свєкръ > свекор; внХрь > вихор); якщо після будь-якого іншого приголосного - вставний $[e]$ (земль > земель; грнвнь > гривень; капиь > капель; $\boldsymbol{п} \mathbf{t c} \mathbf{c} \mathbf{b}$ > пісень).

Редуковані $[b],[b]$ після $[p],[л]$ між приголосними могли бути і в сильній, і в слабкій позиції, залежно від якості наступного складу та наголосу. У сильній позиції [b], [b] після сонорних, як і після всіх інших


глътъка > глотка, бръвы > брови. Редуковані [ъ], [b] у слабкій позиції після $[p],[л]$ занепали, а сонорні перетворилися на складотворчі звуки. Однак на східнослов'янському грунті сонорні не зберігають складотворчої властивості, що й зумовлює появу після плавного в староукраїнській мові голосного $[u]:$ кръшнтн > кршнтн > кришити; гАътатн > гАтатн > глитати; трьвога > трвога > тривога тощо. У діалектах, які дали грунт для творення сучасної російської мови, з'являються голосні $[o],[e]$ (крошить, глотать, тревога); у протобілоруській мові на цьому місці 3'являється голосний [bl] (крышыщьь, гльттащь, трывога).

Ще одне чергування в системі голосних сучасної української мови пов'язується 3 подовженням етимологічних $[o],[e]$. Довгі $[o],[e]$, що утворилися в нових закритих складах після занепаду редукованих у сусідньому складі, на українському грунті дифтонгізувалися, і на їхньому місці утворився голосний, якісно відмінний від етимологічних $[o],[e]$. Довгий $[e]$ незалежно від того, який редукований занепадав у наступному складі ([b], [b]), зазнав таких змін: носъ $>$ нӧс $>$ нуос $>$ нуес $>$ нуис $>$ нуіс $>$ нic. Про такий шлях розвитку свідчать насамперед окремі північноукраїнські говори, у яких на місці етимологічного [o] до сьогодні зберігаються дифтонги.

Інакше розвивався етимологічний голосний $[e]$. Якщо в наступному складі занепадав редукований $[b]$, то звук $[e]$ після подовження став дифтонгізуватися й перейшов у [ie]: неск $>$ нёс > ніес. Дифтонг [ie], перший компонент якого вимовлявся 3 наближенням до [j], зазнав лабіалізації голосного $[e]$, тобто $[e]>[o]$. Далі зміни відбувалися


нуос > нуес > нуис > нуіс > ніс.

Якщо в наступному складі занепадав редукований [b], то етимологічний $[e]$ подовжувався і змінювався в дифтонг [ie], що потім

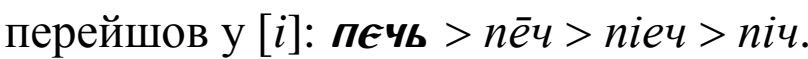


Щоправда, зміна довгих $[o],[e]$, в $[i]$ була непослідовною, деякі слова, групи слів мали свої особливості щодо переходу $[o],[e]$, в $[i]$ (пор.:

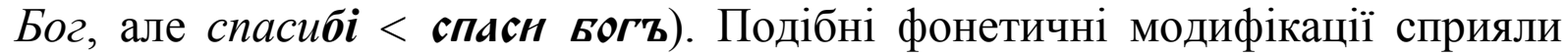
появі в системі голосних такого специфічно українського чергування, як $[o],[e]$ з [i] (пор.: шість - шести, сім - семи, стіл - столу, дім - дому, віл вола, віз - воза тощо $\left.{ }^{3}\right)$.

Унаслідок занепаду редукованих відбулися певні зміни й у системі приголосних. Доки в староукраїнській мові існували редуковані й діяв закон відкритого складу, приголосні не об'єднувалися в будь-які звукосполучення. Лише деякі з них могли належати до одного складу, розміщуючись за тенденцією висхідної звучності. Після занепаду редукованих утворилися нові групи приголосних, які виявилися складними для вимови, а тому окремі звуки в них стали пропускатися.

Спрощення груп приголосних розпочалося ще в староукраїнській мові, відразу ж після занепаду редукованих, і засвідчене в сучасній українській мові: $[$ здн]> [зн]: поздьно > пізно; [ждн] > [жн]: кождьнын > кожний; $[\mathrm{cmл}]>[$ сл]: стьлатн > слати (пор.: постіль); $[\mathrm{cmн}]>[\mathrm{cн}]$ : чьстьнын > чесний; $[$ слн] > [сн]: масньнын > масний (пор.: масло); [сти] $>[c u]:$ мъстьце $>$ місие; $[$ сткл $]>[$ скл]: стькло > скло; $[р д и]>[р и]:$ сьрдьце > серие (пор.: сердечний); [лни] > [ни]: съдньце > сонце; [рнч] > [нч]: горньчарь > гончар (пор.: горня).

Після занепаду редукованих у формах дієприкметників чоловічого роду однини (сучасні дієслова минулого часу) втратився суфіксальний [л],

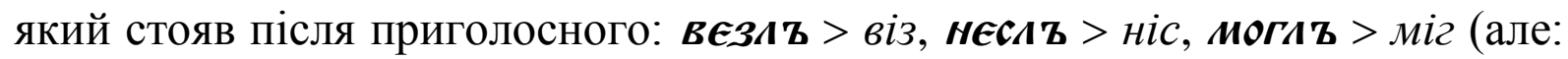
везла, везло, несла, несло, могла, могло). Якщо суфіксальний [л] стояв після голосного і після нього занепадав редукований, то такий [л] змінився на [ÿ]: зналz > знав, пнсалz > писав (але: знала, знало, писала, писало). Звук $[л]$ змінився на $[\check{y}]$ також тоді, коли він стояв після редукованоого [b] або

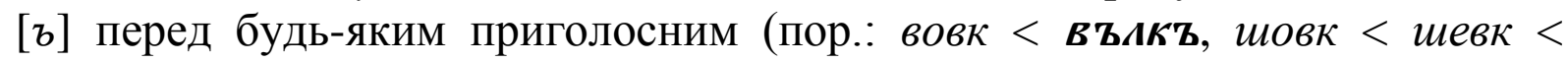

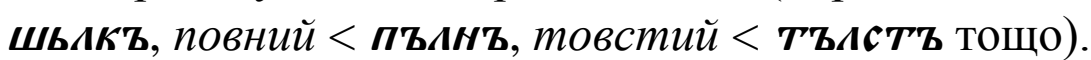

У нових групах приголосних, що утворилися після занепаду редукованих, вимова одних звуків стала впливати на вимогу інших, унаслідок чого виникли й нові асимілятивні та дисимілятивні процеси. Уже у староукраїнській мові засвідчені і прогресивна, i регресивна

\footnotetext{
3 У сучасній українській мові слід розрізняти $[i]$, яке походить $3[o],[e]$ чи [ie]. Дифтонг $[i e]$, що позначався літерою $\boldsymbol{k}$, на українському грунті незалежно від його позиції щодо інших звуків слова змінився в монофтонг $[i]$, який не чергується з іншими голосними й не випадає. У сучасній українській літературній мові такий $[i]$ зберігається як у відкритому, так і в

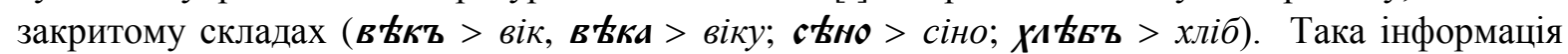
сприятиме закріпленню правил правопису іншомовних прізвищ, зокрема пояснює, чому російські прізвища на зразок Хлебников, Зверев, Серов і т. ін. передаються українською мовою




асиміляції. Наприклад: Бъ чела > Бчела > вчола > бджола (після занепаду редукованого, який перебував перед складом із голосним повного творення у слабкій позиції, глухий приголосний [u] уподібнюється до дзвінкого [б] й змінюється на [дж](у проторосійській мові, навпаки, дзвінкий уподібнюється до глухого, а відтак з'являється слово пчела);

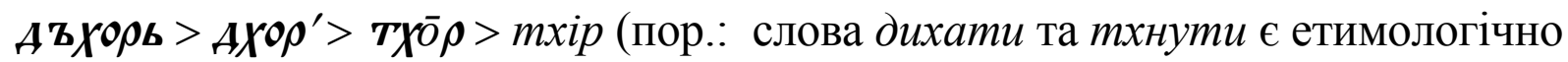
спорідненими). Дисиміляція приголосних належить до непоширених явищ

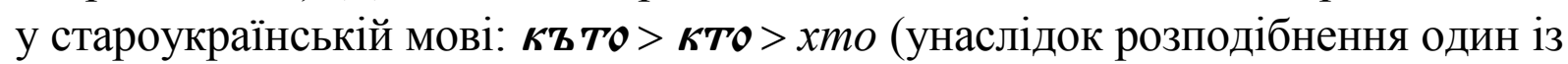
проривних приголосних змінює свою вимогу на фрикативну: $[\kappa]>[x])$; высьшнн > высшнн > вышшнн (асиміляція) > вышчнн (дисиміляція) > вищий.

Специфічно українським фонетичним явищем, репрезентованим сучасною українською літературною мовою, $є$ так звана асиміляція колишнього [j] попередніми приголосними. Редукований [i] перед [j] у ненаголошеній позиції занепадав. На українському грунті звук $[j]$, який після занепаду редукованого [i] став вимовлятися безпосередньо після пом'якшеного приголосного, поступово асимілювався цим приголосним. Асимілювали $[j]$ приголосні $\left[\partial^{\prime}\right],\left[m^{\prime}\right],\left[3^{\prime}\right],\left[c^{\prime}\right],\left[u^{\prime}\right],\left[\jmath^{\prime}\right],\left[\mu^{\prime}\right],[\varkappa],[u],[u]$. Результатом цієї асиміляції стало подовження приголосних в іменниках I i II відміни (стаття, Ілля, знання); в орудному відмінку однини іменників III відміни (сіллю, піччю, тінню) та в особових формах від дієслова лити (ллю, ллєш, лляти): ролнга (роньг =рольја) > рол'ја > ро̄л'л'а > рілля; $($ нью $=$ льју $)>л^{\prime}$ ју $>л^{\prime} л^{\prime} у \mathbf{y}>л л ю$

3 твердими приголосними, зокрема губними та $[p]$, звук $[j]$ не асимілювався: кръвню (кръвью $=$ кръвьју) > кровју > кров'ю (пор.: після


про те, що асиміляція [j] попередніми м'якими приголосними остаточного завершилася тоді, коли губні та $[p]$ уже стверділи. Подібні фонетичні процеси сприяють поглибленню не лише знань із фонетики, але й виробленню правописних норм української мови. Це стосується так само й граматичних історичних явищ. Однак це вже тема окремої наукової праці.

Отже, роль «Історичної граматики української мови» в підготовці майбутнього вчителя-словесника є досить суттєвою. Осмислення історичних фонетичних процесів сприятиме не механічному засвоєнню знань («зазубрюванню»), а усвідомленому їхньому закріпленню. Адже задля того, аби в доступній формі пояснити те чи те явище своїм вихованцям, слід, безумовно, самому знати його суть, природу, закономірності і т. ін.

\section{Література}

1. Безпалько О. П. Історична граматика української мови : [підручник] / О. П. Безпалько, М. К. Бойчук, М. А. Жовтобрюх, І. Й. Тараненко - [2-вид., випр.]. - К. : Радянська школа, 1962. - 510 с.

2. Бурячок А. Давньоруський період в історії східних слов'ян, їх мов і культур / А. Бурячок // Дивослово. -1994. - №5-6. - С. 12-15. 
3. Горський В. С. Давньоруський період в історико-філософському вимірі / В. С. Горський // Мовознавство. -1993. -№2. - С. 31-35.

4. Жовтобрюх М. А. Історія української мови : Фонетика : [підручник] М. А. Жовтобрюх, В. Г. Скляренко. - К. : Вища школа, 1979. - 246 с.

5. Карпенко Ю. О. Українська гіпотеза походження української мови / Ю. О. Карпенко // Мовознавство. - 1993. - №5. - С. 3-8.

6. Медведєв Ф. П. Нариси з історичної граматики української мови : [підручник] / Ф. П. Медведєв. -Харків: Вища школа, 1965. - 262 с.

7. Німчук В. В. Періодизація як напрямок дослідження генези та історії української мови / В. В. Німчук // Мовознавство. - 1998. - №1. - С. 3-12.

8. Степаненко М. 3 історії дослідження витоків української мови / М. Степаненко // Дивослово. - 2000. - №7. - С. 17-19.

9. Сучасна українська літературна мова : [підручник] / А. П. Грищенко, Л. І. Мацько, М. Я. Плющ та ін.; за ред. А. П. Грищенка. - [3-є вид.] - К. : Вища школа, 2002. - 439 с.

10. Царук О. В. Українська мова серед інших слов'янських: етнологічні та граматичні параметри : [монографія] / О. В. Царук. - Дніпропетровськ, 1998. - 323 с.

11. Ющук І. Про походження української мови / I. Ющук // Дивослово. - 1995. №1. - C. 27-33.

Стаття надійшла до редакиії 03.09.2010 p. 